\title{
BÖLGESEL KALKINMA VE İŞGÜCÜ: BİNGÖL İLİ İŞGÜCÜ PİYASASI ÜZERİNE BİR İNCELEME
}

\author{
Regional Development and Labour Force: An \\ Examination of The Labour Market in Bingöl
}

Gökçe CEREV* Sidık BULUT**

Geliş: 21.02.2019/Kabul: 04.07.2019

DOI: $10.33399 /$ biibfad.530198

Öz

Bölgelerarası dengesizliklerin ortadan kaldırılması gelişmekte olan ülkelerin çözmesi gereken önemli bir sorundur. Bölgesel kalkınma politikalarının temelinde de bölgeler arası sosyo ekonomik farkların giderilmesi vardır. Geri kalmış bölgelerin temel sorunlarının başında gelen işsizlik beraberinde diğer ekonomik ve iktisadi sorunları ortaya çıkarmakta ve bölgesel geri kalmışlığın önemli bir nedeni olmaktadır. Gelişmekte olan bir ülke konumunda bulunan Türkiye' de de bölgesel dengesizlikler bulunmaktadır. Bingöl de mevcut durumu doğrultusunda geri kalmış bir il konumundadır. Bu çalışmada öncelikle bölgesel kalkınma ve bölgesel kalkınmada işgücünün önemi açıklanmış, TÜİK (Türkiye İstatistik Kurumu) verileri doğrultusunda Bingöl ilinin işgücü piyasalarının mevcut durumu incelenerek, bölgesel kalkınma açısından önemi ve geleceğe yönelik planlaması değerlendirilmiştir.

Anahtar Kelimeler: Türkiye, Bingöl, Kalkınma, Bölgesel Kalkınma, İşgücü Piyasası

* Doç. Dr., Fırat Üniversitesi, İktisadi ve İdari Bilimler Fakültesi, Çal. Ek. ve End. İlş. Böl., gcerev@fırat.edu.tr, ORCID: https://orcid.org/0000-0001-9908-343X

** Frrat Üniversitesi, İktisadi ve İdari Bilimler Fakültesi, sbulut@fırat.edu.tr, ORCID: https:/ / orcid.org/0000-0002-7941-2950 


\title{
Jel Kodlarn: E2, E24
}

\begin{abstract}
The elimination of inter-regional imbalances is an important problem for developing countries to solve. At the basis of regional development policies is the elimination of socioeconomic differences between regions. Unemployment, which is one of the main problems of underdeveloped regions, also brings other financial and economic problems and is an important cause of regional backwardness. Developing a country in which there are regional imbalances in Turkey. Bingöl is a backward province as to its current situation. In this study, primarily regional development and the importance of the labour force in regional development are explained, the current status of the labour markets in the Bingöl province is examined and its importance in terms of regional development and future planning is evaluated according to TSI (Turkey Statistical Institute) data.
\end{abstract}

Keywords: Turkey, Bingöl, Development, Regional Development, Labour Market,

Jel Codes: E2, E24

\section{Giriş}

Gelişmişlik düzeyi hangi seviyede olursa olsun iktisadi kalkınma ve ekonomik büyüme tüm ülkelerin temel hedefleri arasındadır. Dünyada sosyal ve ekonomik kalkınmada geri kalmış ülkeler olduğu gibi her ülkenin kendi sınırları içinde kalkınma açısından geri kalmış bölgeler de bulunmaktadır. Bölgesel olarak ortaya çıkan bu geri kalmışlık bölgesel kalkınma planları ile çözülmeye çalışılmakta ve ülke genelinde dengeli bir kalkınma sağlanması hedeflenmektedir. Bölgesel kalkınma ekonomik ve iktisadi kalkınmanın bir parçası olarak düşünülürken, aynı zamanda toplumsal açıdan sosyal ve kültürel dengenin de sağlanabilmesinin önemli bir aracı olarak algılanmaktadır. Ülkelerin bazı bölgeleri farklı sebeplerden dolayı hızlı bir şekilde gelişirken bazı bölgeleri ise aynı hızla gelişememekte ve bu durum bölgesel geri kalmışlı̆̆ı ortaya çıkarmaktadır. Bölgesel olarak ülkenin diğer bölgelerine göre daha geri kalmış yerler için bölgesel kalkınma planları öne çıkmaktadır.

Türkiye de gelişmekte olan bir ülke olarak iktisadi kalkınma ve ekonomik büyümeyi gerçekleştirmeyi hedeflemektedir. Ülke genelinde 
uygulanan makro ekonomik politikalar gibi bölgesel olarak uygulanan mikro politikalar da öne çıkmaktadır. Türkiye'nin bazı bölgeleri diğer bölgelere göre daha geri kalmış durumdadır. Uygulanan bölgesel kalkınma planları ile bu bölgelerin dezavantajlı durumları ortadan kaldırılmaya çalışılmaktadır. Bölgesel kalkınmada önemli bir etken de bölgede bulunan işgücünün üretim faktörleri içerisine dahil edilmesidir. İşgücünün üretim faktörleri içinde bulunması ve bir sonraki süreçte kalitesinin ve verimliliğinin artırılması bölgesel kalkınmayı hızlandıracak bir etki göstermektedir. Bingöl ili kalkınmada öncelikli iller arasında bulunmaktadır. Bingöl ilinin iktisadi ve ekonomik kalkınmasının tam olarak sağlanabilmesi için bölgesel işgücünün üretim faktörleri içinde tam olarak kullanılabilmesi önemlidir. Çalışmanın amacı Bingöl ilinin kalkınmasının etkin bir şekilde gerçekleşebilmesi için işgücü piyasalarının genel durumunun incelenmesi ve geleceğe dönük planlamasına katkı sağlanabilmesidir. Bu çalışmada ilk olarak bölgesel kalkınma kavramı açılanmış, ikinci bölümde bölgesel kalkınmada işgücünün önemi irdelenmiş ve son bölümde Bingöl ilinin bölgesel kalkınma bağlamında işgücü piyasası analizi yapılmıştır.

\section{Bölgesel Kalkınma Kavramı}

Bölgesel kalkınma genel olarak tüm ülkeler açısından ekonomik ve iktisadi kalkınmanın önemli bir parçası olarak kabul edilir. Bir ülkede meydana gelen bölgesel farklılıklar zamanla bölgesel yoksulluk, eşitsizlik, sosyal dışlanma, emek piyasalarında enformelleşme gibi farklı sorunları da ortaya çıkarır (Förster vd., 2003:52). Bu durumlarda bölgesel kalkınma politikaları ile bölgeler arasındaki fark, minimuma indirgenmeye çalışılmakta ve ülkenin dengeli bir şekilde topyekûn gelişmesi hedeflenmektedir.

Ekonomik, sosyal ve iktisadi açıdan geri kalmış bölgeler ile gelişmiş bölgeler arasındaki farklılıkları ortadan kaldırmak için uygulanan politikalara bölgesel kalkınma politikaları denir. Bölgesel kalkınma politikalarının dünya genelinde uygulanması sanayi devrimi ile birlikte olmuştur. Özellikle 1929 ekonomik buhranı ile ortaya çıkan bölgesel dengesizliklerin giderilmesi ve yoksulluğun azaltılması yönünde izlenen politikalarda bölgesel kalkınma politikaları öne çıkmaktadır (Anselmo ve Cascio, 2011:467). Sanayi devrimi sonucu ortaya çıkan 
bölgesel kalkınma politikaları günümüzde önemini yitirmemiş ve ülkelerin önemli kalkınma politikaları içinde yer almaya devam etmiştir.

Az gelişmiş ve gelişmekte olan ülkelerin başlica problemi olan iktisadi ve ekonomik kalkınma sorununun temelinde ülke genelinde dengeli bir şekilde kurumsal ve yapısal gelişmenin nasıl sağlanacağı sorusu bulunmaktadır. Bu bağlamda iktisadi kalkınmanın alt boyutları olan nüfus, sanayi, ticaret, eğitim, sağlık, iş gücü gibi farklı alanlardaki politikalarda önemli bir konuma gelmiştir. Bölgesel kalkınma sorunu özellikle gelişmekte olan ülkeler açısından yapısal bir sorun şekline dönüşmüştür. Büyükşehirlerin gelişmenin odak noktası durumuna gelmesi nedeni ile emek ve sosyal piyasaların hareketliliği yükselmiş, bu gelişmenin sonucunda geri kalmış bölgelerde emek ve sermaye piyasaları ciddi eksiklikler yaşamaya başlamıştır. Bu yapısal sorunu ortadan kaldırmak için klasik bölgesel kalkınma politikaları başarı să̆lasa da istenilen sonuca tam olarak ulaşılamamıştır. Sorunun temelinde geri kalmış bölgelerden merkeze doğru olan kaynak aktarımının fazla olması, bölgenin kaynaklarının tam olarak kullanılmaması ve özellikle küresel boyutta ortaya çıkan zamanla da ulusal piyasaları da etkileyen ekonomik krizler bulunmaktadır (Karg1, 2009:22).

\section{Bölgesel Kalkınmada İşgücünün Önemi}

Bir ülke de bölgeler arası farklılıkların ortaya çıkmasının birden çok nedeni bulunmaktadır. Bu nedenler bölgenin coğrafi şartları, üretim potansiyeli, sermaye yetersizliği, iş gücünün yapısı, yoksullaşma oranları, yaşam standartlarının geri kalması şeklinde sıralanabilir. Bölgelerin sosyal ve ekonomik yapısının gelişmişlik düzeyini belirleyen başlıca etkenler, demografik yapı, üretim düzeyi, işgücü ve istihdamın genel durumu, eğitim, sağlık ve yaşam standartları gibi değişkenler olduğu kabul edilmektedir (Erkan vd., 2012:112). Bir bölgenin sosyo ekonomik düzeyi hesaplanırken aynı zamanda ülke içindeki ekonomik ağırlığı, sosyal gelişmişlik düzeyi, milli gelire katkısı, refah düzeyi gibi makro iktisadi etkileri de değerlendirmede bulunulur.

Bölgesel kalkınmanın başarılı olabilmesi için bazı temel yaklaşımlar ile ele alınması gerekir. Bu temel yaklaşımlar;

- Bölgelerde uygulanan programlarla merkezi hükümete fon akışı bağlılığının en düşük seviyede olması, 
- Bölgede özel sermayenin etkinliği artırılması

- Bölgesel aktörlerin üstlendiği rollerin daha etkin bir şekle getirilmesi

- Yapılan planlama ile bölgesel kaynaklardan kapasite ve değer elde edilmesi, uzun süreli fayda sağlamanın hedeflenmesi şeklindedir (Walburn ve Saublens, 2011:480).

Bölgesel kalkınma politikaları yapılırken ilk olarak dışsal ekonomilerin varlığı da dikkate alınmalı ve uygulanacak politikaların diğer etkileri de hesaplanmalıdır. Bölgesel politikaların yan etkileri göz ard1 edilemez. Özellikle iktisadi gelişme eğiliminin bölgesel dağılımı, ülke genelindeki üretim faktörlerinin etkinliği ile ilişkili çıkmaktadır. Bir bölgede iktisadi gelişmenin ne kadar sağlanacağı bölgesel olmayan politikaların da etkisine açı bir durumdur. Bu duruma örnek olarak ülke genelinde uygulanan işsizlikle mücadele politikaların bölgesel etkilerinin birbirinden farklı olması gösterilebilir. Bu durum makro ekonomik politikaların uygulanmasında ortaya çıkan Lucas Eleştiri olarak ta ifade edilmektedir (Ottaviano, 2003:665). Lucas Eleştirisi 1976 yılında Robert Lucas tarafından ele alınan bir makale ile ortaya atılan görüşü ifade etmektedir. Bu yaklaşım, rasyonel bekleyişler teorisinin belkemiğini oluşturmakta ve esasında geçmiş verilere dayandırılan sonuçların gelecek planlamasında her zaman aynı hedefe götürmeyeceği varsayımını açıklamaktaydı (Lucas, 1976).

Bölgesel kalkınma politikalarında temel yöntem planlamadır. Bölgesel politikalar planlı bir esasa göre yapılır ve denetlenir. Planların ana yaklaşımında bölgesel kaynaklar ile talebi artırmak, artan talebi sürdürülebilir bölgesel ekonomi ile karşılama ve devletin bu sistemsel yaklaşıma öncülük etmesi vardır. Bir ülkede ortaya çıan bölgesel dengesizliklerin aşırı boyutta olması ekonomik sistemin yapısal sorununa işarettir. Bölgesel olarak ortaya çıkan iş gücü piyasası dengesizlikleri diğer sorunları da tetikleyecek bir sebep olabilir. Sosyal politikanın temel sorunlarından işsizlik sorunu (Tokol ve Alper; 2018:128) bölgesel olarak ele alındığında üretim faktörleri içinde en önemli yerlerden birine sahip olan bölgesel emeğin israf edildiği sonucunu ortaya çıardığı gibi dengeli istihdam noktasında da eksikliklerin yaşanmasına neden olmaktadır (Zaim, 1990:111-114).

Bölgesel politikaların şekillenmesinde uygulanacak politik araçların önemi büyüktür. Armstrong ve Taylor (2000:74) bölgesel politik araçlar1 
makro politikalar, mikro politikalar ve eşgüdüm politikaları başlığı altında açıklamıştır. Makro politikaların esasında bölgesel gelir ve harcamalara yönelim yaklaşımlar bulunmaktadır. Bölgesel yönetimlere dış ticaret, para ve mali politikaları bölgesel düzeyde belirleyebilmek için yetki verilmesi öne çıkmaktadır. Mikro politikalarda ise üretim girdilerinin bölgesel kaynaklar ile karşılanması ve sermaye ile emeğin bölge içi yeniden dağılımının sağlanabilmesi bulunmaktadır. Eşgüdüm politikaları diğer bölgeler ile denge içeren politikaları ifade etmekte olup bölgesel gelişmenin ülke geneli ile dengeli olmasının önemine vurgu yapmaktadır. Bölgesel kalkınmada kalkınma politikasının temelinde bölgeye dışarıdan kaynak çekme kadar yerel kaynaklı büyüme yaklaşı$\mathrm{m}$ da önemlidir. Bu durum bölgede bulunan işletmelerin desteklenmesi gerekliliğini de ortaya çıarır (Armstrong ve Taylor; 2000:74).

İşüüü piyasaları toplumun temel dinamikleri arasındadır. Üretim sistemleri içinde işgücü piyasalarında bulunan emek faktörü toplumsal gelişimin sağlanabilmesi açısından önemlidir. Bir toplumun iktisadi, ekonomik, sosyal, kültürel ve diğer etkenler içinde gelişebilmesi için işgücü piyasalarının azami ve verimli bir şekilde kullanılması gerekliliktir. Bu bağlamda bölgesel kalkınmanın ana unsurlarından biriside işgücü piyasalarıdır.

Bölgesel kalkınmanın planlı bir şekilde gerçekleşebilmesi için bölgesel işgücü önemli bir araçtır. Bölgesel işgücünün etkin ve verimli bir şekilde bölgesel üretime dahil edilmesi bölgesel refah seviyesini de olumlu şekilde etkileyecektir. Bölgesel işgücü piyasalarının verilerinin iyi değerlendirilmesi, izlenecek olan politikaların esaslarının belirlenmesi yönünden gereklidir. İşgücü verilerinin içinde yer alan iş gücüne katılma oranı bölgenin potansiyel emek faktörünü ortaya koyarken, asıl hedef istihdam oranlarında en yüksek seviyeye ulaşmaktır (Lordoğlu vd., 1999:43). Kalkınma açısından mevcut işgücünün iyi planlanması ve üretim faktörleri içinde etkin bir şekilde değerlendirilmesi önemlidir. Kalkınma işgücüne yönelik politikalar göz ardı edilerek gerçekleştirilemez. İşgücüne yönelik ulusal politikalar gibi her bölgenin kendisine yönelik değerler ile bölgesel işgücü piyasaları politikaları bölgesel kalkınmada önemli bir yere sahiptir (Han ve Kaya, 2004:120-125). Yapılacak olan planlamalarda politika ve programların doğru seçilmesi, değerlendirilmesi ve aksaklıkların giderilmesi yeni politika ve programların geliştirilmesi açısından önemlidir (İslamoğlu vd., 2014:27). 


\section{Bölgesel Kalkınma Açısından Bingöl İlinin Genel Durumu}

Bingöl ili Doğu Anadolu Bölgesi'nin Yukarı Fırat bölümünde yer almaktadır. Doğusu Muş, kuzeyi Erzurum ve Erzincan, Batısı Tunceli ve Elâzı ̆̆, Güneyi ise Diyarbakır illeri ile çevrilidir. İlin Merkez dışında Adaklı, Genç, Karlıova, Kiğı, Solhan, Yayladere ve Yedisu olmak üzere toplam 7 ilçesi bulunmaktadır (www.bingöl.gov.tr). Bingöl yüzölçümü olarak $8254 \mathrm{~km}^{2}$ lik bir alan üzerinde yer almakta ve Türkiye' nin $\% 1,05$ 'ni oluşturmaktadır.

Bingöl ili kalkınma hedefleri doğrultusunda bölgesel kalkınma planı olan "Doğu Anadolu Projesi" içinde yer almaktadır (DAP,2000:15). Doğu Anadolu Projesi ile ülke geneline göre geri kalmış düzeyde olan 14 il proje kapsamına alınmıştır. Bingöl İline komşu olan Erzurum, Erzincan, Muş, Elazığ ve Tunceli illeri de bu proje kapsamında desteklenmektedir. Bu durum geri kalmışlığın sadece Bingöl'e özgü bir olay olmadığını, bölgenin genel sorunu olduğunu göstermektedir. Dikkatle irdelenmesi gereken durum ise Bingöl'ün bölge içindeki genel durumudur (DAP, 2000:16-17). Doğu Anadolu Projesi içinde bulunan iller özellikle iklim durumu, coğrafi şartlar ve sosyo ekonomik yapı nedeni ile Türkiye'nin diğer illerine göre dezavantajlı bir durumdadır. Gelişmiş bölgelerde ortaya çıkan yatırımların üretime dönük ekonomi yaratması ve nüfusun eğitim, kültür, sağlık, yol, enerji gibi farklı faktörlerde ülke ortalaması üzerinde olan göstergeleri gelişmemiş bölgelerde bulunmamaktadır. Az gelişmiş bölgelerin gelişme potansiyelinin düşük olması bu bölgelerin farklı projeler ile desteklenmesini zorunlu kılmıştır. Bingöl İli de genel göstergeleri ile az gelişmiş bir bölge konumundadır. Bingöl bu bağlamda incelendiğinde az gelişmişliğin sosyo kültürel, ekonomik ve demografik niteliklerini taşımaktadır. Bu nitelikler ekonomik ve sosyal açıdan, kişi başına gelirin ülke ortalaması altında olması, gelir dağılımında eşitsizlik, istihdamın niteliksel bozukluğu, verimsiz üretim, yetersiz sanayi, yetersiz eğitim, kadınların toplum içindeki konumu, yüksek kayıt dişılık, yetersiz altyapı ve kalitesiz bir yaşam olarak toplumsal hayatı derinden etkilemektedir (Dinler, 2001:28-30).

Bingöl ilinin hem bölgesel hem de ulusal seviyede sosyal ve ekonomik düzeyde gelişmişliğini en son 2011 yılında Kalkınma Bakanlığ1 tarafından yapılan SEGE-2011 İllerin ve Bölgelerin Sosyo-Ekonomik Gelişmişlik Araştırmasına göre değerlendirdiğimizde (SEGE:2013), en alt düzeyde düşük gelişmişlik grubunda yer aldığı sonucuna ulaşmaktayız. 
Raporda illerin gelişmişlik düzeyi 2012 tarihli ve 3305 sayılı Bakanlar Kurulu Kararı doğrultusunda 6 kademe altında değerlendirilmiştir. Değerlendirme sonucunda en yüksek gelişmişlik verisi 4.51 ile İstanbul'dan elde edilmiş, en düşük veri ise -1,73 ile Muş'tan elde edilmiştir. Bingöl ise -1,1920 sonucu ile 81 il içinde 72'nci sırada yer almıştır. Veriler bölgesel olarak ele alındığında Bingöl'ün komşu illerinden Muş 81. Sıra ile Türkiye' nin en geri kalmış ili olurken, Diyarbakır 67, Erzurum 59, Tunceli 58, Erzincan 45, Elazığ 39'ncu sırada yer almıştır. Genel olarak bölge illeri Türkiye ortalamasının altında sosyo ekonomik verilere sahipken Bingöl bölgenin en geri kalmış illeri arasında yer almaktadır.

Şekil 1: Altı Temel Düzeye Göre Bölgelerin Gelişmişlik Seviyesi

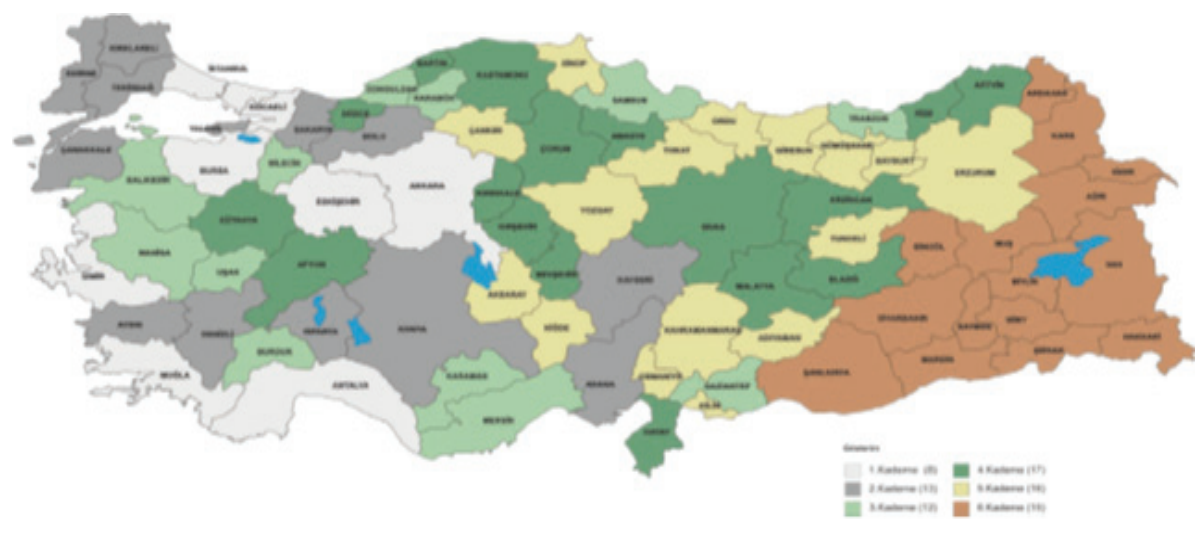

Kaynak: SEGE-2011 Raporu (SEGE, 2013:52)

Raporda iller aynı zamanda istatistiki bölge birimleri sınıflarına göre sosyo-ekonomik düzeyde sıralanmıştır. 26 seviyede sıralanmış bölgeler içinde Bingöl TRB1 Bölgesinde Malatya, Elazığ ve Tunceli illeri ile birlikte 20'nci sırada yer almıştır (SEGE,2013:74). Genel olarak değerlendirildiğinde Bingöl ili hem ulusal hem de bölgesel göstergelere göre geri kalmış bir seviyededir. Bu durum Bingöl'ün kalkınmasının bölge için önemli olduğunu ortaya koymakta ve Bingöl'ün işgücü piyasalarının ilin kalkınmasında önemli bir rolü olduğunu göstermektedir.

\section{Bingöl İli İşgücü Piyasalarının Mevcut Durumu}

İşüüü piyasası, emeğini arz edenler ile bu emeği talep edenlerin belirli bir fiyat ve üretim miktarı üzerinden karşı karşıya geldikleri 
ve anlaştıkları piyasadır (Gündoğan ve Biçerli,2003:4). İşgücü, mevcut piyasaların ayırt edici olan ve potansiyel durumunun veri analizi yapılmasında doğru sonuçların elde edilmesi için tanımlayıcıdır (ILO, 1990:2). Bingöl ilinin kalkınması için mevcut işgücü piyasalarının tanımlanması ve geleceğe yönelik planlamasının yapılması önemlidir. Bingöl'ün işgücü piyasalarının potansiyelini ortaya koyan ilk aşama nüfus ve nüfusun genel yapısıdır.

\subsection{Bingöl İl Nüfusunun Genel Yapısı}

Bir bölgenin nüfusu ve nüfusunun yapısı işgücü piyasalarının potansiyelini ortaya koymaktadır. Nüfusun nicel ve nitel yapısı ile geleceğe yönelik yapılacak işgücü planlamaları yatırımların şekli belirlenmekte, ekonomik ve iktisadi gelişmenin önü açılmaktadır.

Bingöl ilinde merkez dahil 8 ilçe 11 belde ve 315 köy bulunmaktadır. Bingöl ilinin il ve ilçe nüfus bilgileri 2018 yılı adrese dayalı nüfus verilerine göre Tablo 1'de verilmiştir. Tablo 1 verilerine göre 2018 yılında Bingöl'ün toplam nüfusu 281.205 kişidir. Nüfus açısından en büyük ilçeler Merkez ile birlikte Genç ve Solhan ilçeleridir. Nüfusun \%59,61'i il ve ilçe merkezlerinde yaşarken, $\% 40,39^{\prime}$ u ise belde ve köylerde yaşamaktadır. Toplam nüfusun \%56,95'i merkez ilçede yaşamaktadır. Bingöl ili genel yapısı ile merkezde ilçe nüfusunun yoğunlaştığı merkez dışında genel olarak kırsal kesimde nüfusun bulunduğu bir il görünümü sergilemektedir.

Tablo 1: Bingöl İlinin İlçe ve Toplam Nüfus Sayısı (2018)

\begin{tabular}{|l|c|c|c|c|}
\hline \multicolumn{1}{|c|}{ İl ve İlçe } & Toplam & $\begin{array}{c}\text { Ill ve İlçe } \\
\text { Merkezi }\end{array}$ & $\begin{array}{c}\text { Belde ve } \\
\text { Köyler }\end{array}$ & $\begin{array}{c}\text { Nüfus } \\
\text { Yüzdesi }\end{array}$ \\
\hline BINGÖL & $\mathbf{2 8 1 . 2 0 5}$ & $\mathbf{1 6 8 . 1 8 0}$ & $\mathbf{1 1 3 . 0 2 5}$ & --- \\
\hline Merkez & 160.165 & 117.556 & 42.609 & $\% 56.96$ \\
\hline Adakl1 & 9.315 & 3.566 & 5.749 & $\% 3.31$ \\
\hline Genç & 3.428 & 16.565 & 21.863 & $\% 13.67$ \\
\hline Karliova & 29.650 & 7.551 & 22.099 & $\% 10.54$ \\
\hline Kiğ1 & 5.013 & 2.832 & 2.181 & $\% 1.78$ \\
\hline Solhan & 33.618 & 17.756 & 15.862 & $\% 11.95$ \\
\hline Yayladere & 2.139 & 959 & 1.180 & $\% 0.76$ \\
\hline Yedisu & 2.877 & 1.395 & 1.482 & $\% 1.02$ \\
\hline
\end{tabular}

Kaynak: www.tüik.gov.tr, Erişim Tarihi: 07.02.2019 
Bingöl ili nüfusunun cinsiyet ve yaş dağılımı TÜİK verilerine göre Tablo 2' de verilmiştir. Bingöl'ün nüfusunun \%51,04' ü erkek (143.524 kişi), \% 48,96's kadın (137.681 kişi) nüfusundan meydana gelmektedir. İl ve ilçe merkezlerinde yaşayan erkek nüfus 84.834 kişi, kadın nüfus 83.346 kişiden oluşmaktadır. Belde ve köylerde yaşayan kadın nüfusu 54.335 kişi, erkek nüfusu 58.690 kişiden oluşmaktadır. Bingöl ilinde kadın ve erkek nüfusu birbirine yakın rakamlar sergilemektedir. Bu durum özellikle kadın istihdamı açısından önemli bir faktördür. Bingöl ilinin nüfusun yaş dağılımı incelendiğinde 96.842 kişi 0-14 yaş aralığında, 165.606 kişi 15-64 yaş aralığında ve 18.757 kişi 65 yaş ve üstü grubunda yer almaktadır. Nüfusun \%58.89'u çalışma çağındaki nüfustan meydana gelmektedir. Çalışma çağındaki nüfusun oranı Bingöl'ün işgücü potansiyelini ortaya koyarken yapılacak istihdam yaratan doğru yatırımların bölgenin kalkınması açısından ne kadar önemli olduğunu destekleyen bir veri durumundadır.

Tablo 2. Bingöl İli Nüfusunun Cinsiyet ve Yaş Gruplarına Göre Dağılımı (2018)

\begin{tabular}{|l|l|}
\hline Nüfus Dağılımı (Cinsiyet-Yaş) & Bingöl İli \\
\hline Toplam & $\mathbf{2 8 1 . 2 0 5}$ \\
\hline Cinsiyet & \\
\hline Kadın & 137.681 \\
\hline Erkek & 143.524 \\
\hline İl ve İlçe Merkezi (Kadın) & 83.346 \\
\hline İl ve İlçe Merkezi (Erkek) & 84.834 \\
\hline Belde ve Köyler (Kadın) & 54.335 \\
\hline Belde ve Köyler (Erkek) & 58.690 \\
\hline Toplam & \\
\hline Yaş & \\
\hline 0-14 Yaş & 96.842 \\
\hline 15-64 Yaş & 165.606 \\
\hline 65+ Yaş & 18.757 \\
\hline Toplam & $\mathbf{2 8 1 . 2 0 5}$ \\
\hline
\end{tabular}

Kaynak: www.tüik.gov.tr, Erişim Tarihi: 07.02.2019

Bingöl ilinin nüfusunun genel özellikleri TÜİK verilerine göre Tablo 3'de verilmiştir. Tablo 3 verilerine göre Bingöl ilinin nüfus artış hızı 
binde 2.87 düzeyinde meydana gelirken, nüfus yoğunluğu kilometrekareye 34 kişi olarak ortaya çıkmıştır. Bingöl ilinin hane halkı büyüklüğü Türkiye ortalamasının üzerinde 3.9 kişi olarak meydana gelmiştir. Nüfus bağlılık oranı \%50.6 olan Bingöl'de genç bağl1lığ1 \% 40.5, yaşlı bağlılığ \%10 düzeyinde gerçekleşmiştir. Net iç göç hızı ise \%0.1 olarak meydana gelmiştir. Bu durum Bingöl'ün nüfus artış potansiyeli olan genç bir nüfusa sahip olduğunu göstermektedir. Hane halkı büyüklüğü bölge ortalamasına yakın düzeyde olan Bingöl için genç nüfus yapısı kalkınma için önemli bir fırsattır.

Tablo 3. Bingöl Nüfusu Genel Özellikleri (2018)

\begin{tabular}{|l|l|l|}
\hline & Bingöl & Türkiye \\
\hline Nüfus Artış Oranı & $\%$ 2.87 & $\%$ 12.4 \\
\hline Nüfus Yoğunluğu & 34 kişi & 107 kişi \\
\hline Hane Halkı Büyüklüğü & 3.9 kişi & 3.4 kişi \\
\hline Nüfus Bağımlılık Oranı & $\% 50.6$ & $\% 47.4$ \\
\hline Genç Bağımlılık Oranı & $\% 40.5$ & $\% 34.5$ \\
\hline Yaşlı Bağımlılık Oranı & $\% 10.0$ & $\% 12.9$ \\
\hline Net Göç Hızı (İç Göç) & $\% 0.1$ & -- \\
\hline
\end{tabular}

Kaynak: www.tüik.gov.tr, Erişim Tarihi: 07.02.2019

Bingöl ilinin genel ekonomik göstergeleri TÜİK verilerine göre Tablo 4 ' de verilmiştir. Bingöl ekonomik olarak kişi başına düşen gayri safi yurt içi hasıla bakımından hem dolar hem de Türk lirası cinsinden Türkiye ortalamasının oldukça altında bir görünüm sergilemektedir. Türkiye'deki ihracatın \%0.01'ni gerçekleştiren Bingöl ithalatın ise \%0.07'sini gerçekleştirmektedir. Bingöl'de yaklaşık.,6 kilometrekare olan tarım alanı ilin genel yüzölçümünün dörtte birinin tarım amaçlı kullanıldığını göstermektedir. İlin genel büyüklüğüne göre iyi bir küçükbaş hayvan potansiyeline sahip Bingöl'ün bu veriler ile tarım ve hayvancılığın il genelinde önemli bir sektör olduğunu göstermektedir. 
Tablo 4. Bingöl Ekonomisi Genel Özellikleri (2018)

\begin{tabular}{|l|l|l|}
\hline & Bingöl & Türkiye \\
\hline Kişi Başına GSYH (TL) & 19.205 & 38.681 \\
\hline Kişi Başına GSYH (Dolar) & 5.264 & 10.602 \\
\hline Toplam İhracat (Bin Dolar) & 156.992 .940 & 1.688 \\
\hline Toplam İthalat (Bin Dolar) & 233.799 .651 & 16.555 \\
\hline Toplam İşlenen Tarım Alanı (m2) & 20.036 .992 & 26.494 \\
\hline Küçük Baş Hayvan Sayısı (Adet) & 44.312 .308 & 504.732 \\
\hline
\end{tabular}

Kaynak: www.tüik.gov.tr, Erişim Tarihi: 07.02.2019

\subsection{Bingöl İli İşgücü Piyasalarının Genel Analizi}

Bingöl ilinin işgücü piyasasının 2008 ile 2013 yılları arasında il düzeyinde gerçekleşen genel göstergeleri Tablo 5' de TÜİK verileri üzerinden ayrıntılı olarak verilmiştir. Genel göstergelerin içeriğinde işgücüne katılma oranı, işsizlik oranı ve istihdam oranı göstergeleri il düzeyinde bulunmaktadır.

Tablo 5 verilerine göre Bingöl ilinin işgücüne katılma oranı yıllar itibari ile artış göstermiştir. 2008 yılında \%39.1 düzeyinde olan işgücüne katılma oranı 2013 yılında \%54.6 düzeyine yükselmiştir. Bingöl ilinin işgücüne katılma oranları Türkiye ortalamasının üzerinde bir görünüm sergilemiş 2013 yılı itibari ile Türkiye genelinde \%48.3 olan İşgücüne Katılma Oranı Bingöl'de ortalama 6 puan fazla gerçekleşmiştir. Bingöl ilinin işsizlik göstergeleri y1llar itibari ile olumlu gelişme göstermiş 2008 yılında \%1.8 ile Türkiye ortalaması üzerinde gerçekleşen işsizlik oranı yıllar itibari ile düşüş göstermiş ve 2013 yılında \% 9'luk Türkiye ortalamasının 2 puan altında \%7 ile gerçekleşmiştir. Bingöl ilinin istihdam oranları da olumlu bir görünüm sergilemiş ve 2008 yılında Türkiye ortalamasının altında \%33.3 ile gerçekleşen istihdam artarak 2013 yılında \% 43.9'luk Türkiye ortalamasının ortalama 7 puan üstünde \%50.8 gerçekleşmiştir. 2008 ile 2013 yılları arasında Bingöl'ün işgücü piyasaları olumlu yönde gerçekleşmiş, işgücüne katılma ve istihdam oranları artarken işsizlik oranları düşüş eğilimi göstermiştir. 
Tablo 5. Bingöl İli İşgücü Göstergeleri (2008-2013/15-64 Yaş)

\begin{tabular}{|c|c|c|c|c|c|c|}
\hline \multirow{2}{*}{ Y1l } & \multicolumn{2}{|c|}{$\begin{array}{c}\text { İşücüne Katılma } \\
\text { Oranı (\%) }\end{array}$} & \multicolumn{2}{|c|}{$\begin{array}{c}\text { İşsizlik Oranı } \\
\text { (\%) }\end{array}$} & \multicolumn{2}{|c|}{$\begin{array}{c}\text { İstihdam Oranı } \\
\text { (\%) }\end{array}$} \\
\cline { 2 - 7 } & Bingöl & Türkiye & Bingöl & Türkiye & Bingöl & Türkiye \\
\hline $\mathbf{2 0 0 8}$ & 39.1 & 44.9 & 14.8 & 10.0 & 33.3 & 40.4 \\
\hline $\mathbf{2 0 0 9}$ & 43.3 & 45.7 & 17.8 & 13.1 & 35.6 & 39.8 \\
\hline $\mathbf{2 0 1 0}$ & 46.3 & 46.5 & 12.5 & 11.1 & 40.5 & 41.3 \\
\hline $\mathbf{2 0 1 1}$ & 51.2 & 47.4 & 9.6 & 9.1 & 46.3 & 43.1 \\
\hline $\mathbf{2 0 1 2}$ & 50.7 & 47.6 & 8.3 & 8.4 & 46.5 & 43.6 \\
\hline $\mathbf{2 0 1 3}$ & 54.6 & 48.3 & 7.0 & 9.0 & 50.8 & 43.9 \\
\hline
\end{tabular}

Kaynak: www.tüik.gov.tr, Erişim Tarihi: 07.02.2019

TÜİK İl düzeyinde iş gücü piyasası göstergelerini 2013 yılına kadar yayınlamış, 2013 yılından sonra göstergeleri bölgesel düzeyde açıklamıştır. TÜİK 26 bölgede verdiği göstergelerde Bingöl ili Malatya, Tunceli ve Elâzığ illeri ile TRB1 bölgesinde yer almıştır. Bingöl ilinin 2013 ile 2017 yılları arasında işgücü piyasası göstergeleri bölgesel olarak ele alınacaktır.

TRB 1 Bölgesinin işgücü göstergeleri Tablo 6'da ayrıntılı olarak verilmiştir. Tablo 6 verilerine göre bölgenin işgücü yıllar itibari ile artış göstererek 619 bin kişi seviyesine ulaşmıştır. İşgücü içinde özellikle bölge açısından öne çıkan durum kadın işgücündeki artış olmuştur. 2014 yılında toplam işgücü içinde \%29.89'luk paya sahip kadın işgücü 2017 yılında toplam işgücü içinde \%33.44'lük düzeye ulaşmıştır. Bölge açısından kadın iş gücüne katılma oranı dönemsel olarak artış göstermiş 2014 yılında kadınlarda \%29.6, erkeklerde \%72 olan oran 2017 yılında kadınlarda \%36.9, erkeklerde \%76.1 düzeyine yükselmiştir. Bölge açısından kadın işsizliği 2014 yılında \%10.2 düzeyinde bulunurken 2017 yılında \%12 düzeyine yükselmiş, erkek işsizlik oranları ise 2014 yılında \%6.8 düzeyinde görünüm sergilerken 2017 y1lında \%5 seviyesinde gerçekleşmiştir. Bölgenin istihdam oranları da yıllar itibari ile artış göstermiş 2014 yılında \%26.6 olan kadın istihdamı 2017 yılında \%32.5 düzeyine yükselmiştir. Bölgenin erkek istihdamı ise 2014 yılında \%67.1 düzeyinde gerçekleşirken 2017 yılında \%72.3 düzeyine yükselmiştir. Bölgenin genel 
işgücü göstergeleri olumlu yönde gelişme göstermektedir. Artan iş gücüne katılım oranı ve istihdam oranı ile birlikte olumlu bir seyir ortaya koyan işsizlik rakamları bu durumun önemli bir göstergesidir. Bölge işgücü piyasaları açısından öne çıkan önemli bir unsur da kadın işgücünün piyasa içerisinde kendisine giderek daha fazla yer bulmasıdır.

Tablo 6. TRB1 Bölgesi İşgücü Göstergeleri (2004-2018/15-64 Yaş)

\begin{tabular}{|l|c|c|c|c|c|c|c|c|}
\hline \multirow{2}{*}{ Gösterge } & \multicolumn{2}{|c|}{$\mathbf{2 0 1 4}$} & \multicolumn{2}{c|}{2015} & \multicolumn{2}{c|}{2016} & \multicolumn{2}{c|}{2017} \\
\cline { 2 - 9 } & Kadın & Erkek & Kadın & Erkek & Kadın & Erkek & Kadın & Erkek \\
\hline $\begin{array}{l}\text { İsücü } \\
(1000)\end{array}$ & 168 & 394 & 170 & 410 & 187 & 407 & 207 & 412 \\
\hline İKO (\%) & 29.6 & 72 & 30.4 & 72.5 & 32.9 & 75.3 & 36.9 & 76.1 \\
\hline $\begin{array}{l}\text { İssizlik O } \\
\text { (\%) }\end{array}$ & 10.2 & 6.8 & 9.4 & 7.9 & 12.2 & 8 & 12 & 5 \\
\hline $\begin{array}{l}\text { İstihdam } \\
\text { O. (\%) }\end{array}$ & 26.6 & 67.1 & 27.6 & 66.8 & 28.9 & 69.3 & 32.5 & 72.3 \\
\hline
\end{tabular}

Kaynak: www.tüik.gov.tr, Erişim Tarihi: 07.02.2019

TRB 1 Bölgesinde istihdamın sektörel dağılımı Tablo 7'de verilmiştir. İstihdamın sektörel dağılımında öne çıkan ilk nokta sanayi istihdamının yıllar içinde düşüş eğiliminde olduğudur. 2014 yılında toplam \%18.1 olan sanayi istihdamının 2017 yılında \%17 düzeyine gerilemiştir. Sanayi istihdamı içinde kadın istihdamı \%8.5'lik düzeyle düşük bir düzeyde ortaya çıkmıştır. Bölgede istihdamın yapısı ağırlıklı olarak hizmet sektöründe meydana gelmektedir. Hizmet sektörünün toplam istihdamı 2014 yılında \%50.4 düzeyinden 2017 yılında \%48.8 düzeyine gerilemiş, hizmet sektörü içinde kadın istihdam oranı \%39.9 düzeyinden \%41.7 düzeyine yükselirken, erkek istihdam oranı ise \%54.7 düzeyinden \%52.1 düzeyine gerilemiştir. Hizmet sektöründeki istihdam kadın işgücü açısından olumlu bir görünüm sergilemiştir. Bölgenin tarım istihdam oranları yatay bir seyir trendi gösterirken özellikle 2017 yılında \%34.2’ lik istihdam düzeyine yükselmesi bölgesel göstergeler lehine tarım politikalarının önemini ortaya koymaktadır. Bölgenin tarım istihdamı içerisinde kadın istihdamı \%49.8 düzeyinde gerçekleşmiştir. Bölgenin istihdam yapısı genel olarak değerlendirildiğinde sanayi yatırımlarının yetersiz olması 
istihdamın hizmet ve tarım sektörü yönünde yoğunlaşmasını ortaya çıkarmıştır.

Tablo 7. TRB1 Bölgesi İstihdamın Sektörel Dağılımı (2004-2018/15-64 Yaş)

\begin{tabular}{|l|l|l|l|l|l|l|l|l|l|}
\hline & \multicolumn{3}{|c|}{ Tarım } & \multicolumn{3}{c|}{ Sanayi } & \multicolumn{3}{c|}{ Hizmet } \\
\hline Yı1 & Kadın & Erk. & Top. & Kadın & Erk. & Top. & Kadın & Erk. & Top. \\
\hline $\mathbf{2 0 1 4}$ & 51.9 & 23.2 & 31.5 & 8.2 & 22.1 & 18.1 & 39.9 & 54.7 & 50.4 \\
\hline $\mathbf{2 0 1 5}$ & 49.1 & 21.1 & 29.3 & 6.7 & 22.7 & 18.0 & 44.2 & 56.7 & 52.7 \\
\hline $\mathbf{2 0 1 6}$ & 42.9 & 23.3 & 29.4 & 7.6 & 19.3 & 15.7 & 49.5 & 57.3 & 54.9 \\
\hline $\mathbf{2 0 1 7}$ & 49.8 & 26.9 & 34.2 & 8.5 & 21.0 & 17.0 & 41.7 & 52.1 & 48.8 \\
\hline
\end{tabular}

Kaynak: www.tüik.gov.tr, Erişim Tarihi: 07.02.2019

\section{Sonuç ve Değerlendirme}

Bölgeler arası farklılıklar hem gelişmiş hem de gelişmekte olan ülkelerde önemli bir sorundur. Gelişmekte olan ülkeler açısından bölgesel farklılıkların giderilmesi ve bölgeler arası gelişmişlik düzeyinin birbirine yakın düzeye getirilmesi sürdürülebilir ekonomik ve iktisadi kalkınma ile sosyal ve toplumsal adaletin sağlanması açısından önemlidir. Bölgeler arası farklılıkların giderilmesi için uygulanan önemli bir yöntem ise bölgesel kalkınma politikalarıdır. Bölgesel kalkınma politikaları ile bir ülkede geri kalmış bölgelerin dezavantajlı yönlerinin giderilerek ülke içindeki gelişmiş bölgelere yakın sosyo ekonomik düzeye ulaşılması hedeflenir. Bölgesel kalkınma politikalarının bu hedefe ulaşmasında önemli bir araçta geri kalmış bölgenin potansiyel işgücü ve işgücü piyasalarının genel durumudur.

Bingöl ili mevcut durumu ile bölgesel kalkınma politikaları içinde yer alan ve kalkınmada öncelikli konuma sahip bir ildir. Bingöl ilinin işgücü piyasalarının güçlü ve istikrarlı olması ilin kalkınması açısından önemli bir avantajdır. Bu yaklaşım ile Bingöl ilinin işgücü piyasalarının genel yapısı değerlendirildiğinde;

Bingöl ilinin genç ve çalışma çağında bir nüfusa sahip olması, işgücü potansiyelini yükseltmektedir. Bingöl ilinin son ylllar için artan işgücüne katılma oranı ve istihdam düzeyi ile yatay bir seyir gösteren işsizlik oranı bölgesel yatırımların işgücü piyasalarına olumlu yansıdığını göster- 
mektedir. Özellikle kadın işgücünün artan potansiyeli bölge açısından iktisadi değer yaratmakta ve kalkınmanın önemli bir aracı olmaktadır. İstihdamın sektörel dağılımı içinde sanayi yatırımlarının zayıf yönü son dönemde hayvancılık ve tarım yatırımlarının desteklenmesi ile giderilmeye çalışılmıştır. Bölgenin coğrafi ve iklimsel şartları göz önünde bulundurulduğunda doğru tarım ve hayvancılık yatırımları işgücüne önemli girdiler sağlayacaktır. İşüüü piyasaları açısından artan istihdam oranları ile bölge halkının gelir ve refah seviyesi artmakta ve bu durum bölgesel kalkınmaya olumlu yansımaktadır.

Bingöl' ün işgücü piyasalarının olumlu yapısının, gelecek dönemler içinde sürdürülebilmesi, bölgesel kalkınma açısından önemlidir. Mevcut durum içinde başta işgücü piyasalarına yeni girecek genç nüfusun piyasa ile entegrasyonun sağlanması ve gençlere yönelik işgücü uyum programlarının yapılması gereklidir. Bölgenin işgücü potansiyeli aç1sından önemli bir konumda bulunan kadın işgücünün dönemsel olarak olumlu gelişen yapısının, müteakip dönemler içinde sürdürebilmesi için kadınlara yönelik desteklerin artırılması önemli bir konudur. İstihdamın sektörel dağılımını göz önünde bulundurarak istihdam dışında kalan işgücünün piyasaya çekilmesi için gerekli projelerin planlaması bölge açısından önemlidir.

Bingöl ili bulunduğu coğrafi konum açısından bölgesel kalkınma içinde önemli bir yere sahiptir. Bingöl ilinin işgücünün olumlu gelişen mevcut yapısının sürdürülmesi hem Bingöl'ün kalkınmasında hem de bölgenin kalkınmasında önemli bir etken olacaktır. Bingöl ilinin gelişmesi ve kalkınması için ilin işgücü piyasaları stratejik bir konumdadır. Ortaya konulan olumlu işgücü politikalarının müteakip dönemlerde sürdürülmesi Bingöl'ün hızlı ve istikrarlı bir şekilde kalkınmasını sağlayacaktır. 


\section{Kaynakça}

Anselmo, A. D., ve Cascio, L. L. (2011). “Towards a New Era for Regional Development: Investing in Leadership". Local Economy, 26(6-7), 467-472.

Armstrong, H. J. ve Taylor (2000). Regional Economics and Policy, Blackwell, Publishers, Oxford.

DAP (2000). Doğu Anadolu Projesi Ana Planı, T.C. Başbakanlık DPT Müsteşarlığ1, http:/ / www.dap.gov.tr

Dinler, Z. (2001). Bölgesel İktisat, Ekin Kitabevi Yayınları, Bursa.

Erkan, B. Şentürk, M. ve Akbaş, Y. E. (2012). “Bingöl İlinin Türkiye' nin İhracat ve GSYH'sına Katkısının Alt Sektörler İtibarıyla İncelenmesi". İstanbul Ticaret Üniversitesi Sosyal Bilimler Dergisi, 11 (21), 107-126.

Förster, M. Jesuit, D. ve Smeeding, T. (2003). Regional Poverty And Income Inequality In Central And Eastern Europe Evidence From The Luxembourg Income Study, United Nations University Discussion Paper, No. 2003/65.

Gündoğan, N. ve Biçerli, M. K. (2003). Çalışma Ekonomisi, AÜ Yayınları: 1461, Eskişehir

Han E., ve Kaya A. E. (2004). İktisadi Kalkınma ve Büyüme, Anadolu Üniversitesi Yayınları No:831, Eskişehir

http:/ / www.bingol.gov.tr/ cografi-yapi; Erişim Tarihi: 04.02.2019

http://www.tuik.gov.tr/Start.do; jsessionid=lWwVck2pD4JjfR0TcNtYGPhh xvGSDh1nML12M0SbnG6LQH6XJLVt!2129963349, Erişim Tarihi: 07.02.2019.

ILO (1990). "Surveys of Economically Active Population, Employment, Unemployment And Underemployment". Journal of the Royal Statistical Society: Series D (The Statistician), 41(2), 249-250

İslamoğlu, E. Namal, M.K. ve Köleoğlu, Y. (2014). “Bir Aktif İstihdam Politikası Aracı Olarak Girişimcilik Programlarının Etkinliği. KOSGEB Yeni Girişimcilik Destek Programı Örneği. Kafkas Üniversitesi İ̈BF Dergisi, Cilt: 5, Say1 :8, Sayfa: 25-44

Kargı, N. (2009). “Bölgesel Kalkınma Yaklaşımlarındaki Gelişmeler ve $A B$ Perspektifi Altında Türkiye'nin Bölgesel Politika Analizi”. International Journal of Economic and Administrative Studies, 1 (3): 19-39 
Lordoğlu, K. Özkaplan N. ve Törüner M. (1999). Çalışma İktisadı, Beta Basım Yayım Dağıtım, İstanbul.

Lucas, R. E. (1976). “Econometric Policy Evaluation: A critique”. In Carnegie-Rochester conference series on public policy (Vol. 1, No. 1, pp. 19-46).

Ottaviano, G. (2003). "Regional Policy in the Global Economy: Insights from New Economic Geography”. Regional Studies, 37(6-7), 665-673.

SEGE (2013). İllerin ve Bölgelerin Sosyo-Ekonomik Gelişmişlik Sıralaması Araştırması 2011, Kalkınma Bakanlığı Bölgesel Gelişme ve Yapısal Uyum Genel Müdürlüğü, Ankara

Tokol, A. ve Alper Y. (2018). Sosyal Politika, 9. Baskı, Dora Basımevi, Bursa

Walburn, D. ve Saublens, C. (2011). “Regional Economic Development Policy İn Europe: Where Next". Local Economy, 26 (6-7): 473-485.

Zaim S. (1990). Çalışma Ekonomisi, 8. Bask1, Filiz Kitapevi, İ̀stanbul 